eCommons@AKU

April 2011

\title{
Helicobacter pylori: association with gall bladder disorders in Pakistan
}

Javed Yakoob

Aga Khan University

M. R. Khan

Aga Khan University

Z. Abbas

Aga Khan University

W. Jafri

Aga Khan University

R.Azmi

Aga Khan University

See next page for additional authors

Follow this and additional works at: https://ecommons.aku.edu/pakistan_fhs_mc_med_med Part of the Digestive System Diseases Commons, and the Nephrology Commons

\section{Recommended Citation}

Yakoob, J., Khan, M., Abbas, Z., Jafri, W., Azmi, R., Ahmad, Z., Naeem, S., Lubbad, L. (2011). Helicobacter pylori: association with gall bladder disorders in Pakistan. British Journal of Biomedical Science, 68(2), 59-64.

Available at: https://ecommons.aku.edu/pakistan_fhs_mc_med_med/50 
Authors

Javed Yakoob, M. R. Khan, Z. Abbas, W. Jafri, R. Azmi, Z. Ahmad, S. Naeem, and L. Lubbad 


\title{
Helicobacter pylori: association with gall bladder disorders in Pakistan
}

\author{
J. Yakoob, M. R. Khan, Z. Abbas, W. Jafri, R. Azmi, Z. Ahmad, S. Naeem \& L. \\ Lubbad
}

To cite this article: J. Yakoob, M. R. Khan, Z. Abbas, W. Jafri, R. Azmi, Z. Ahmad, S. Naeem \& L. Lubbad (2011) Helicobacter pylori: association with gall bladder disorders in Pakistan, British Journal of Biomedical Science, 68:2, 59-64, DOI: 10.1080/09674845.2011.11730324

To link to this article: https://doi.org/10.1080/09674845.2011.11730324

\section{Published online: 23 May 2016.}

Submit your article to this journal $\square$

Џ Article views: 6

Citing articles: 8 View citing articles ¿ 


\section{Helicobacter pylori: association with gall bladder disorders in Pakistan}

\author{
J. YAKOOB ${ }^{\star}$, M. R. $\mathrm{KHAN}^{\dagger}$, Z. ABBAS*, W JAFRI ${ }^{\star}, \mathrm{R}^{*} \mathrm{AZMI}^{\dagger}$, \\ Z. AHMAD $^{\ddagger}$, S. NAEEM ${ }^{\dagger}$ and L. LUBBAD $\$$ \\ Departments of Medicine ${ }^{*}$, Surgery ${ }^{\dagger}$, Pathology $y^{\ddagger}$ and Biomedical Sciences ${ }^{\S}$, \\ The Aga Khan University, Karachi, Pakistan
}

\section{Introduction}

Helicobacter species colonise the human gastrointestinal and hepatobiliary tract, usually resulting in chronic infection coupled with an inflammatory host response. This colonisation is associated with a variety of gastrointestinal and hepatobiliary diseases. ${ }^{1}$ The enterohepatic helicobacters such as Helicobacter hepaticus and $H$. bilis, first recognised in laboratory rodents, have been considered a component of the normal flora. $H$. hepaticus colonises the lower gastrointestinal tract, including the caecum, colon and hepatobiliary system of mice and causes chronic active hepatitis and typhlocolitis in immunocompetent mice and can lead to liver carcinoma in male mice of susceptible strains. ${ }^{2-5} \mathrm{H}$. bilis was also identified in inbred mice with chronic hepatitis. ${ }^{6}$ Patients with chronic liver disease have been reported to have significantly higher levels of antibody to $H$. bilis and H. hepaticus compared to healthy subjects.?

These urease-producing bacteria may induce stone formation by hydrolysing urea into ammonia that increases the $\mathrm{pH}$ and favours precipitation of salts that lead to subsequent stone formation..$^{8,9}$ It has also been demonstrated that cholesterol gallstone-prone C57L/J mice rarely develop gallstones unless they are infected with certain cholelithogenic enterohepatic Helicobacter species. ${ }^{10}$ In a previous study, all four urease-positive Helicobacter species (H. hepaticus, H. bilis, H. pylori and H. mustelae) were shown to be capable of precipitating calcium. ${ }^{11}$ This suggests that urease-positive Helicobacter species that are able to survive in or colonise the bile ducts may induce the formation of gallstones, both directly via their urease activity or indirectly via the immune response. ${ }^{11} \mathrm{H}$. pylori has also been shown to colonise areas of gastric metaplasia in the gall bladder, producing histological changes similar to those seen in the gastric mucosa. ${ }^{12}$ Isolation of $H$. pylori DNA from gallstones further supports its presence in the gall bladder. ${ }^{12}$

Helicobacter species have been detected in patients with biliary tract cancer significantly more frequently than in controls. ${ }^{13-15}$ There are reports that biliary Helicobacter

\section{ABSTRACT}

Helicobacter species colonise the biliary tract and therefore this study explores the relationship between of Helicobacter pylori and cholecystitis. Bile and gall bladder tissue samples were obtained from 144 patients who underwent cholecystectomy. Of these, 89 had chronic cholecystitis with cholelithiasis, 44 had gall bladder carcinoma and 11 had gall bladder polyps. Histopathology examination included special staining and immunohistochemistry (IHC), while Helicobacter species (H. pylori, H. bilis and $H$. hepaticus) were detected by the polymerase chain reaction (PCR). Sequencing and BLAST query of PCR products was undertaken and samples were considered to contain H. pylori if both PCR and IHC were positive. Immunohistochemistry for $H$. pylori was positive in 22 (25\%) cases compared to five $(9 \%)$ in the control group $(P=0.02)$. Testing (PCR) for $16 \mathrm{~S}$ rDNA was positive in $23(26 \%)$ cases compared to six $(11 \%)$ controls $(P=0.03)$. Negative PCR results were obtained for $H$. bilis and $H$. hepaticus. Twenty-four (89\%) were positive by both $16 \mathrm{~S}$ rDNA PCR and IHC for H. pylori $(P<0.001)$. Both PCR for 16S rDNA and IHC were positive in $21(24 \%)$ cases compared to five $(9 \%)$ controls $(P=0.03)$. Sequencing of $16 \mathrm{~S}$ rRNA and glmM PCR products were consistent with $H$. pylori. In conclusion, $H$. pylori DNA was demonstrated in cases of chronic cholecystitis and gall bladder carcinoma associated with cholelithiasis, but this association requires further study.

KEY WORDS: Bile.

Cholecystitis.

Cholelithiasis.

Gallbladder diseases.

Helicobacter pylori.

colonisation is frequent in countries with a high incidence of gall bladder carcinoma, the highest incidence rates in this region being reported for women in Delhi, India $(21.5 / 100,000)$, and in Karachi, Pakistan $(13.8 / 100,000) \cdot{ }^{16}$ In a previous study, the incidence of gallstones was determined in cases of carcinoma of the gall bladder. In this series, 93\% of patients had gallstones $(85 \%$ were female, age range: 27-65 years) ${ }^{17}$ A recent study in Karachi looked at the frequency of biliary infection associated with cholelithiasis. Results showed that a total of $36 \%$ had bile culture positive for Escherichia coli (17\%) Klebsiella (9\%), Pseudomonas (6\%), Staphylococcus aureus (2\%), Salmonella (1\%) and Bacteroides fragilis $(1 \%) .{ }^{18}$ However, $H$. pylori also has a high prevalence in the local population. ${ }^{19}$

The prevalence of H. pylori in bile and the gall bladder has not been examined previously in patients with gall bladder disorders in Pakistan. Therefore, this study aims to 
investigate the frequency of $H$. pylori in gall bladder tissue and bile from patients who underwent cholecystectomy for cholelithiasis, and compare them with those having cholecystectomy for gall bladder polyps (GBP) and carcinoma (GBC).

\section{Materials and Methods}

One hundred and forty-four patients undergoing cholecystectomy were enrolled on the study between January 2008 and December 2009 (101 [70\%] females, 43 [30\%] males; mean age: $49 \pm 14$ [range 18-84]). All presented with recurrent upper right abdominal pain. Eighty-nine patients who had cholecystectomy for cholelithiasis associated with chronic cholecystitis were included in the study group. The control group comprised 55 patients who underwent cholecystectomy, 11 for GBP and 44 for GBC. Of the GBC patients, 25\% (11/44) also had gallstones. None of the GBP patients had stones. The study was approved by the institutional ethics review committee.

Histopathology examination included haematoxylin and eosin (H\&E), Giemsa and Warthin-Starry staining and immunohistochemistry (IHC). Gall bladder tissue and bile were used to extract DNA for PCR of the H. pylori $16 \mathrm{~S}$ ribosomal DNA (rDNA) and phosphoglucosamine mutase $(g \operatorname{lm} M)$ gene. If positive, these were further evaluated for cytotoxin-associated gene $(\operatorname{cag} A)$ and vacuolating cytotoxinA (vacA) gene alleles. Diagnosis of $H$. pylori infection was established when both PCR and IHC were positive. To detect $H$. bilis and $H$. hepaticus, specific primer sets for $16 \mathrm{~S}$ ribosomal RNA (rRNA) sequences of $H$. bilis and $H$. hepaticus were used.

Immunohistochemistry staining for $H$. pylori was performed using streptavidin peroxidase (SP). Anti-H. pylori antibody (Dako) was diluted (1 in 10), and phosphatebuffered saline (PBS) was used as blank control, normal blood serum as a negative control, and sections of gastric mucosa containing $H$. pylori as the positive control.

\section{DNA extraction}

Extraction of DNA from bile and gall bladder tissue was performed as described previously. ${ }^{20}$ Briefly, $450 \mu \mathrm{L}$ bile was diluted with an equal volume of PBS ( $\mathrm{pH} 8$ ) and centrifuged at $14000 \times g$ for $20 \mathrm{~min}$. The supernatant was discarded and

Table 1. Oligonucleotide primers used to amplify the 16S rRNA and Helicobacter pylori-specific genes.

\begin{tabular}{|c|c|c|c|c|}
\hline Gene & Sequence ( $5^{\prime}$ to $\left.3^{\prime}\right)$ & Reaction conditions & Amplicon size (bp) & Position \\
\hline $16 \mathrm{~S}$ rRNA & $\begin{array}{l}\text { C97 5'-GCT ATG ACG GGT ATC C-3' } \\
\text { C } 98 \text { 5'-GAT TIT ACC CCT ACA CCA-3' }\end{array}$ & $\begin{array}{l}94^{\circ} \mathrm{C} \text { for } 5 \mathrm{~min} \\
94^{\circ} \mathrm{C} \text { for } 1 \mathrm{~min} \\
55^{\circ} \mathrm{C} \text { for } 1 \mathrm{~min} \\
72^{\circ} \mathrm{C} \text { for } 90 \mathrm{sec}(35 \text { cycles }) \\
72^{\circ} \mathrm{C} \text { for } 7 \mathrm{~min}\end{array}$ & 400 & $\begin{array}{l}276-291 \\
681-698\end{array}$ \\
\hline gImM & $\begin{array}{l}\text { GGATAAGCTITAGGGGTGTTAGGGG } \\
\text { GCTTACПTTCTAACACTAACGCGC }\end{array}$ & $\begin{array}{l}94^{\circ} \mathrm{C} \text { for } 1 \mathrm{~min} \\
56^{\circ} \mathrm{C} \text { for } 1 \mathrm{~min} \\
72^{\circ} \mathrm{C} \text { for } 1 \mathrm{~min}(35 \text { cycles }) \\
72^{\circ} \mathrm{C} \text { for } 5 \mathrm{~min}\end{array}$ & 296 & \\
\hline $\begin{array}{l}\text { cagA } \\
\text { D008 } \\
\text { R008 }\end{array}$ & $\begin{array}{l}\text { ATAATGCTAAATTAGACAACTTGAGCGA } \\
\text { TTAGAATAATCAACAAACATCACGCCAT }\end{array}$ & $\begin{array}{l}94^{\circ} \mathrm{C} \text { for } 5 \mathrm{~min} \\
94^{\circ} \mathrm{C} \text { for } 1 \mathrm{~min} \\
55^{\circ} \mathrm{C} \text { for } 1 \mathrm{~min} \\
72^{\circ} \mathrm{C} \text { for } 1.5 \mathrm{~min} \text { (35 cycles) } \\
72^{\circ} \mathrm{C} \text { for } 5 \mathrm{~min}\end{array}$ & 297 & $1751-2048$ \\
\hline $\begin{array}{l}\text { vacA } \\
\text { M1 } \\
\text { VA3-F } \\
\text { MA3-R }\end{array}$ & $\begin{array}{l}\text { GGTCAAAATGCGGTCATGG } \\
\text { CCATTGGTACCTGTAGAAAC }\end{array}$ & $\begin{array}{l}95^{\circ} \mathrm{C} \text { for } 5 \mathrm{~min} \\
95^{\circ} \mathrm{C} \text { for } 1 \mathrm{~min} \\
52^{\circ} \mathrm{C} \text { for } 1 \mathrm{~min} \\
72^{\circ} \mathrm{C} \text { for } 1 \mathrm{~min} \text { (35 cycles) } \\
72^{\circ} \mathrm{C} \text { for } 5 \text { min }\end{array}$ & 290 & $2741-3030$ \\
\hline $\begin{array}{l}\text { VA4-F } \\
\text { VA4-R }\end{array}$ & $\begin{array}{l}\text { GGAGCCCCAGGAAACATTG } \\
\text { CATAACTAGCGCCTTGCAC }\end{array}$ & & 352 & 976-1327 \\
\hline $\begin{array}{l}\text { S1a } \\
\text { SS1-F } \\
\text { VA1-R }\end{array}$ & $\begin{array}{l}\text { GTCAGCATCACACCGCAAC } \\
\text { CTGCTTGAATGCGCCAAAC }\end{array}$ & & 190 & 866-1055 \\
\hline $\begin{array}{l}\text { S1b } \\
\begin{array}{r}\text { SS3-F } \\
\text { VA1-R }\end{array}\end{array}$ & $\begin{array}{l}\text { AGCGCCATACCGCAAGAG } \\
\text { CTGCTTGAATGCGCCAAAC }\end{array}$ & & 187 & \\
\hline $\begin{array}{l}\text { H. bilis } \\
\mathrm{F} \\
\mathrm{R}\end{array}$ & $\begin{array}{l}\text { CAGAACTGCATTGAAACTAC } \\
\text { AAGCTCTGGCAAGCCAGC }\end{array}$ & $\begin{array}{l}94^{\circ} \mathrm{C} \text { for } 5 \mathrm{~min} \\
94^{\circ} \mathrm{C} \text { for } 1 \mathrm{~min} \\
55^{\circ} \mathrm{C} \text { for } 1 \mathrm{~min} \\
72^{\circ} \mathrm{C} \text { for } 1 \mathrm{~min}(35 \text { cycles) } \\
72^{\circ} \mathrm{C} \text { for } 5 \mathrm{~min}\end{array}$ & 418 & \\
\hline $\begin{array}{l}\text { H. hepaticus } \\
\text { F } \\
\text { R }\end{array}$ & $\begin{array}{l}\text { GAAACTGTTACTCTG } \\
\text { TCAAGCTCCCCGAAGGG }\end{array}$ & $\begin{array}{l}94^{\circ} \mathrm{C} \text { for } 5 \mathrm{~min} \\
94^{\circ} \mathrm{C} \text { for } 1 \mathrm{~min} \\
55^{\circ} \mathrm{C} \text { for } 1 \mathrm{~min} \\
72^{\circ} \mathrm{C} \text { for } 1 \mathrm{~min} \text { (35 cycles) } \\
72^{\circ} \mathrm{C} \text { for } 5 \mathrm{~min}\end{array}$ & 405 & \\
\hline
\end{tabular}


Table 2. Diagnostic yield of various tests in different groups.

\begin{tabular}{|c|c|c|c|c|}
\hline & & $\begin{array}{l}\text { Cholecystitis with cholelithiasis } \\
\qquad(n=89)\end{array}$ & $\begin{array}{l}\text { Control group } \\
\quad(n=55)\end{array}$ & $P$ value \\
\hline $\begin{array}{l}\text { Polymerase chain reaction } \\
16 \mathrm{~S} \text { rDNA }\end{array}$ & $\begin{array}{l}\text { Positive } \\
\text { Negative }\end{array}$ & $\begin{array}{l}23(26) \\
66(74)\end{array}$ & $\begin{array}{c}6(11) \\
49(89)\end{array}$ & 0.03 \\
\hline gImM & $\begin{array}{l}\text { Positive } \\
\text { Negative }\end{array}$ & $\begin{array}{l}21(24) \\
68(76)\end{array}$ & $\begin{array}{c}5(9) \\
50(91)\end{array}$ & 0.03 \\
\hline cagA & $\begin{array}{l}\text { Positive } \\
\text { Negative }\end{array}$ & $\begin{array}{c}4(5) \\
85(95)\end{array}$ & $\begin{array}{c}0(0) \\
55(100)\end{array}$ & 0.30 \\
\hline VacA s1am1 & $\begin{array}{l}\text { Positive } \\
\text { Negative }\end{array}$ & $\begin{array}{c}4(5) \\
85(95)\end{array}$ & $\begin{array}{c}0(0) \\
55(100)\end{array}$ & 0.30 \\
\hline VacA s1am1 & $\begin{array}{l}\text { Positive } \\
\text { Negative }\end{array}$ & $\begin{array}{c}8(9) \\
81(91)\end{array}$ & $\begin{array}{c}3(6) \\
52(94)\end{array}$ & 0.53 \\
\hline Immunohistochemistry & $\begin{array}{l}\text { Positive } \\
\text { Negative }\end{array}$ & $\begin{array}{l}22(25) \\
67(75)\end{array}$ & $\begin{array}{c}5(9) \\
50(91)\end{array}$ & 0.02 \\
\hline $\begin{array}{l}\text { Criteria used for the confirmation of } \boldsymbol{H} \text {. } \\
16 \mathrm{~S} \text { rRNA PCR }+ \text { Immunohistochemistry }\end{array}$ & $\begin{array}{l}\text { nfection } \\
\text { Positive } \\
\text { Negative }\end{array}$ & $\begin{array}{l}21(24) \\
68(76)\end{array}$ & $\begin{array}{c}5(9) \\
50(91)\end{array}$ & 0.03 \\
\hline PCR gImM+ immunohistochemistry & $\begin{array}{l}\text { Positive } \\
\text { Negative }\end{array}$ & $\begin{array}{l}21(24) \\
68(76)\end{array}$ & $\begin{array}{c}5(9) \\
50(91)\end{array}$ & 0.03 \\
\hline
\end{tabular}

the pellet was mixed with $250 \mu \mathrm{L}$ PBS and recentrifuged. Bile sample pellets were incubated with lysis buffer $(50 \mathrm{mmol} / \mathrm{L}$ Tris $\mathrm{HCl}$ [pH 7.2], $1 \mathrm{mmol} / \mathrm{L}$ EDTA, $0.45 \%$ sodium dodecyl sulphate [SDS], $0.45 \% \mathrm{NP}-40$ and $100 \mathrm{mg} / \mathrm{mL}$ protease $\mathrm{K}$ ) for $20 \mathrm{~h}$ at $56^{\circ} \mathrm{C}$ and extracted (x2) with phenol-chloroform (equal volumes). After another extraction with chloroform, the DNA was precipitated with absolute ethanol and dissolved in TE buffer $(10 \mathrm{mmol} / \mathrm{L}$ Tris $[\mathrm{pH} 8]$ and $1 \mathrm{mmol} / \mathrm{L}$ EDTA).

Extraction of DNA from gall bladder tissue was performed as described previously. ${ }^{21}$ Gall bladder tissue $(50 \mathrm{mg})$ was homogenised to uniformity in $400 \mu \mathrm{L}$ sterile water and centrifuged at $8000 \mathrm{xg}$ for $10 \mathrm{~min}$. Then, $400 \mu \mathrm{L}$ lysis buffer (100 mmol/L NaCl, 10 mmol/L Tris-HCl [pH 8], 25 mmol/L EDTA, $0.5 \%$ SDS $)$ and $10 \mu \mathrm{L}$ proteinase $\mathrm{K}(10 \mathrm{mg} / \mathrm{mL})$ were added. Incubation was carried out at $56^{\circ} \mathrm{C}$ for $20 \mathrm{~h}$, and proteinase $\mathrm{K}$ was inactivated by boiling for $10 \mathrm{~min}$. This was followed by phenol-chloroform extraction and ethanol precipitation. The resulting pellet was allowed to dissolve in $35 \mu \mathrm{L}$ TE buffer $(10 \mathrm{mmol} / \mathrm{L}$ Tris- $\mathrm{HCl}[\mathrm{pH} 7.4]$ and $0.1 \mathrm{mmol} / \mathrm{L}$ EDTA [pH 8]) for $20 \mathrm{~h}$ at $37^{\circ} \mathrm{C}$. Samples were stored at $-20^{\circ} \mathrm{C}$ before PCR amplification was performed. DNA content and purity was determined by measuring absorbance at $260 \mathrm{~nm}$ and $280 \mathrm{~nm}$ using a spectrophotometer (Beckman DU-600, USA).

\section{PCR amplification}

Samples were amplified by Helicobacter genus-specific $16 \mathrm{~S}$ rRNA primers. The forward (C97) and reverse (C98) primers amplified a product of approximately $400 \mathrm{bp} .{ }^{21}$ Samples generating a positive result were subsequently analysed with eight different sets of primers. Two specific primer sets were used to detect $H$. bilis and $H$. hepaticus $16 \mathrm{~S}$ rRNA sequences previously described..$^{22}$ The other six specific primers used were to look for the $\operatorname{glm} M$ and vacA alleles (e.g., s1a, s1b, s1m1 and s1m2, and cagA genes), ${ }^{23,24}$ which encode potential virulence factors in $H$. pylori. Nucleotide primer sequences and PCR conditions are shown in Table 1. The amplified products were analysed on $2 \%(\mathrm{w} / \mathrm{v})$ agarose gel stained with ethidium bromide and observed under short-wavelength ultraviolet light.

\section{Sequence analyses}

Amplicons were purified from the agarose gel by a DNA extraction kit (Roche, Indianapolis, Indiana, USA). Three amplicons from the gall bladder were sequenced to verify that they were $H$. pylori $16 \mathrm{~S}$ rRNA and $g \operatorname{lm} M$ genes. Sequence analysis was performed (Macrogen, Seoul, South Korea) using primers for $16 \mathrm{~S}$ rRNA and glmM genes. Sequence comparison was carried out using the BLAST program and the GenBank database.

\section{Statistical analysis}

The Statistical Package for Social Science (SPSS Release 16, standard version) was used for data analysis. Descriptive analysis was performed for demographic and clinical features. Results were presented as mean \pm SD for quantitative variables and number (percentage) for qualitative variables. Univariate analysis was performed using the independent sample $t$-test, and Pearson's $\chi^{2}$ test and Fisher's Exact test were used where appropriate. $P<0.05$ was considered statistically significant. The kappa $(\kappa)$ test was performed to assess agreement between two methods of testing.

\section{Results}

Histological examination for $H$. pylori proved inconclusive by H\&E, Giemsa and Warthin-Starry staining. Immunohistochemistry demonstrated $H$. pylori in $25 \%$ $(22 / 89)$ of the case specimens and in $9 \%(5 / 55)$ of the controls $(P=0.02$; Table 2). 
Table 3a. Comparison of cholecystitis with cholelithiasis and gall bladder carcinoma without stones.

\begin{tabular}{|c|c|c|c|c|}
\hline & & $\begin{array}{l}\text { Cholecystitis } \\
\text { with cholelithiasis } \\
\qquad(n=89)\end{array}$ & $\begin{array}{l}\text { Gall bladder } \\
\text { carcinoma } \\
\quad(n=38)\end{array}$ & $P$ value \\
\hline $\begin{array}{l}\text { PCR } \\
\text { 16SrRNA }\end{array}$ & $\begin{array}{l}\text { Positive } \\
\text { Negative }\end{array}$ & $\begin{array}{l}23(26) \\
66(74)\end{array}$ & $\begin{array}{c}1(3) \\
37(97)\end{array}$ & 0.001 \\
\hline GImM & $\begin{array}{l}\text { Positive } \\
\text { Negative }\end{array}$ & $\begin{array}{l}21(10) \\
68(90)\end{array}$ & $\begin{array}{c}0(0) \\
38(100)\end{array}$ & 0.201 \\
\hline Immunohistochemistry & $\begin{array}{l}\text { Positive } \\
\text { Negative }\end{array}$ & $\begin{array}{l}22(25) \\
67(75)\end{array}$ & $\begin{array}{c}0(0) \\
38(100)\end{array}$ & $<0.001$ \\
\hline
\end{tabular}

Univariate analysis was performed by using the independent sample $t$-test, Pearson $\chi^{2}$ test and Fisher Exact test were also used as appropriate. $P<0.05$ was considered statistically significant. Percentages shown in parentheses.

Results of PCR amplification of 16S rDNA, glmM, cagA and vacA in the different groups are shown in Table 2 . None of the samples showed PCR positivity for either $H$. bilis or H. hepaticus. H. pylori $16 \mathrm{~S}$ rDNA PCR and IHC were both positive in $24 \%$ (21/89) of study cases compared to $9 \%(5 / 55)$ of the control group ( $P=0.03$; Table 2$)$. The glmM gene PCR and IHC were also both positive in $24 \%$ (21/89) of study group cases compared to $9 \%(5 / 55)$ of the control group $(P=0.03$; Table 2).

There was significant correlation between PCR for H. pylori $16 \mathrm{~S}$ rDNA and IHC, with $20 / 23$ in the study group positive by both techniques $(\kappa=85 \%, P<0.001)$. Both PCR for
$16 \mathrm{~S}$ rDNA and IHC were positive in $21(24 \%)$ cases of cholecystitis associated with gallstones, in no cases of gall bladder carcinoma without cholelithiasis $(P<0.001)$ and in $5 / 6(83 \%)$ cases of gall bladder carcinoma with cholelithiasis $(P=0.005$; Tables $3 \mathrm{a}-\mathrm{c})$.

Three 16S rRNA and glmM gene PCR products were selected at random for sequencing. The $16 \mathrm{~S}$ rRNA gene sequences HM596599-HM596601 and $\operatorname{glmM}$ gene sequences GQ334379-GQ334382 produced significant alignments with NC 008086.1 H. pylori HPAG1, NC 000915.1 H. pylori 26695, NC 000921.1 H. pylori J99 and NC 008229.1.

Table 3b. Comparison of cholecystitis with cholelithiasis and gall bladder carcinoma with stones.

\begin{tabular}{|c|c|c|c|c|}
\hline & & $\begin{array}{l}\text { Cholecystitis } \\
\text { with cholelithiasis } \\
\qquad(n=89)\end{array}$ & $\begin{array}{l}\text { Gall bladder carcinoma } \\
\text { with stones } \\
(n=6)\end{array}$ & $P$ value \\
\hline \multicolumn{5}{|l|}{ PCR } \\
\hline \multirow[t]{2}{*}{$16 \mathrm{~S}$ rRNA } & Positive & $23(26)$ & $5(83)$ & \multirow[t]{2}{*}{0.008} \\
\hline & Negative & $66(74)$ & $1(17)$ & \\
\hline \multirow[t]{2}{*}{ gImM } & Positive & $21(10)$ & $5(83)$ & \multirow[t]{2}{*}{0.005} \\
\hline & Negative & $68(90)$ & $1(17)$ & \\
\hline \multirow[t]{2}{*}{ Immunohistochemistry } & Positive & $22(25)$ & $5(83)$ & \multirow[t]{2}{*}{0.007} \\
\hline & Negative & $67(75)$ & $1(17)$ & \\
\hline
\end{tabular}

Univariate analysis was performed by using the independent sample $t$-test, Pearson $\chi^{2}$ test and Fisher Exact test were also used as appropriate. $P<0.05$ was considered statistically significant. Percentages shown in parentheses.

Table 3c. Comparison of cholecystitis with cholelithiasis and gall bladder polyp.

\begin{tabular}{llccc} 
& & & & \\
& $\begin{array}{c}\text { Cholecystitis } \\
\text { with cholelithiasis } \\
(n=89)\end{array}$ & $\begin{array}{c}\text { Gall bladder } \\
\text { polyp } \\
(n=11)\end{array}$ & $P$ value \\
\hline PCR & Positive & $23(26)$ & $0(0)$ & 0.06 \\
16S rRNA & Negative & $66(74)$ & $11(100)$ & 0.11 \\
\hline gImM & Positive & $21(24)$ & $0(0)$ & 0.17 \\
\hline Immunohistochemistry & Negative & $68(74)$ & $11(100)$ & $0(0)$ \\
\hline
\end{tabular}

Univariate analysis was performed by using the independent sample $t$-test, Pearson $\chi^{2}$ test and Fisher Exact test were also used as appropriate. $P<0.05$ was considered statistically significant. Percentages shown in parentheses. 


\section{Discussion}

This study demonstrated that H. pylori DNA was positive in $24 \%$ in a study group comprising patients undergoing cholecystectomy for cholelithiasis associated with chronic cholecystitis by PCR and IHC $(P=0.03$ and $P=0.03$, respectively). However, it was not demonstrated in gall bladder carcinoma without stones or in cases of gall bladder polyps.

It is interesting that $\mathrm{H} \& \mathrm{E}$, Giemsa and Warthin-Starry stains were inconclusive while IHC results correlated with PCR findings. This could be explained by the absence of areas of intestinal metaplasia in the gall bladder mucosa, as described previously. ${ }^{12}$ It is also known that after treatment for chronic active gastritis, $H$ pylori can change shape and decrease in number, making identification and differentiation from extracellular debris or mucin difficult. In such cases, IHC improves the rate of identification, even when histological examination and cultures were negative. ${ }^{25,26}$

This study did not attempt to culture H. pylori from the bile or the gall bladder as poor culture yield is known to follow storage of these specimens. Direct culture of clinical samples would increase the probability of in vitro $H$. pylori isolation and identification.

In a recent study, Chen et al. demonstrated H. pylori in the gall bladder of patients with chronic cholecystitis, ${ }^{27}$ in whom the incidence of bile reflux was significantly higher. H. pylorilike bacteria were found in $14 \%$ of gall bladders using the Warthin-Starry silver stain and in 7\% using IHC. ${ }^{27}$ They also demonstrated that in patients with cholecystitis associated with cholelithiasis there was a high incidence of gastric H. pylori infection. Similar results were reported by Caldwell et al. who studied H. pylori infection rate and gastritis in patients with chronic calculus cholecystitis before and after cholecystectomy and found that the duodenogastric reflux increased after cholecystectomy. ${ }^{28}$

Bile regurgitation appears to play a role in selecting H. pylori that are resistant to bile salts, and, while aggravating any injury to the gastric mucosa, they are able to enter the gall bladder from the duodenum. ${ }^{14}$ Also, low bile $\mathrm{pH}$ has been shown to permit survival of H. pylori. ${ }^{29}$

Biliary infection, cystic and common bile duct obstruction and acute cholecystitis have been shown to decrease bile $\mathrm{pH}$, therefore increasing the likelihood of infection with Helicobacter species in these diseases. ${ }^{30,31}$ The implications of these studies are that $H$. pylori can resist the effect of bile salts and survive under basic conditions.

It is known that increased incidence of hepatobiliary disease is associated with chronic carriage of Salmonella typhi and also a high risk of hepatobiliary cancer. ${ }^{32}$ Whether or not $H$. pylori has a similar relationship in patients with chronic cholecystitis can only be ascertained by a large prospective study of hepatobiliary disease using appropriate tests for H. pylori diagnosis. Thus, currently it is only possible to conclude that $H$. pylori is present in the bile and gall bladder of Pakistani patients with chronic cholecystitis associated with cholelithiasis and gall bladder carcinoma associated with cholelithiasis, and is involved in the immunopathogenesis of gall bladder disorders in some cases.

The authors thank the staff of the Juma Research Laboratory for help during this study.

\section{References}

1 Fox JG. The non- $H$. pylori helicobacters: their expanding role in gastrointestinal and systemic diseases. Gut 2002; 50: 273-83.

2 Fox JG, Dewhirst FE, Tully JG et al. Helicobacter hepaticus sp. nov, a microaerophilic bacterium isolated from livers and intestinal mucosal scrapings from mice. J Clin Microbiol 1994; 32: 1238-45.

3 Fox JG, Li X, Yan L et al. Chronic proliferative hepatitis in A/JCr mice associated with persistent Helicobacter hepaticus infection: a model of Helicobacter-induced carcinogenesis. Infect Immun 1996; 64: 1548-58.

4 Fox JG, Lee A. The role of Helicobacter species in newly recognized gastrointestinal tract diseases of animals. Lab Anim Sci 1997; 47: 222-55.

5 Kullberg MC, Ward JM, Gorelick PL et al. Helicobacter hepaticus triggers colitis in specific-pathogen-free interleukin-10 (IL-10)deficient mice through an IL-12- and gamma interferondependent mechanism. Infect Immun 1998; 66: 5157-66.

6 Fox JG, Rogers AB, Whary MT et al. Helicobacter bilis-associated hepatitis in outbred mice. Comp Med 2004; 54: 571-7.

7 Ananieva O, Nilsson I, Vorobjova T, Uibo R, Wadstrom T. Immune responses to bile-tolerant Helicobacter species in patients with chronic liver diseases, a randomized population group, and healthy blood donors. Clin Diagn Lab Immunol 2002; 9: 1160-4.

8 Kaufman HS, Magnuson TH, Lillemoe KD, Frasca P, Pitt HA. The role of bacteria in gall bladder and common duct stone formation. Ann Surg 1989; 209: 584-91.

9 Hammes F, Boon N, de Villiers J, Verstraete W, Siciliano SD. Strain-specific ureolytic microbial calcium carbonate precipitation. Appl Environ Microbiol 2003; 69: 4901-9.

10 Maurer KJ, Rogers AB, Ge Z et al. Helicobacter pylori and cholesterol gallstone formation in $\mathrm{C} 57 \mathrm{~L} / \mathrm{J}$ mice: a prospective study. Am J Physiol Gastrointest Liver Physiol 2006; 290: G175-82.

11 Belzer C, Kusters JG, Kuipers EJ, Vanvliet AH. Urease-induced calcium precipitation by Helicobacter species may initiate gallstone formation. Gut 2006; 55: 1678-9.

12 Misra V, Misra SP, Dwivedi M, Shouche Y, Dharne M, Singh PA. Helicobacter pylori in areas of gastric metaplasia in the gall bladder and isolation of $H$. pylori DNA from gallstones. Pathology 2007; 39: 419-24.

13 Kobayashi T, Harada K, Miwa K, Nakanuma Y. Helicobacter genus DNA fragments are commonly detectable in bile from patients with extrahepatic biliary diseases and associated with their pathogenesis. Dig Dis Sci 2005; 50: 862-7.

14 Bulajic M, Maisonneuve P, Schneider-Brachert W et al. Helicobacter pylori and the risk of benign and malignant biliary tract disease. Cancer 2002; 95: 1946-53.

15 Fukuda K, Kuroki T, Tajima Y et al. Comparative analysis of Helicobacter DNAs and biliary pathology in patients with and without hepatobiliary cancer. Carcinogenesis 2002; 23: 1927-31.

16 Randi G, Franceschi S, La Vecchia C. Gall bladder cancer worldwide: geographical distribution and risk factors. Int J Cancer 2006; 118: 1591-602.

17 Zarin M, Ahmed M, Gohar A. Incidence of gallstones in carcinoma gall bladder patients. Pak J Surg 2005; 21: 19-22.

18 Sattar I, Aziz A, Rasul S, Mehmood Z, Khan A. Frequency of infection in cholelithiasis. J Coll Physicians Surg Pak 2007; 17: 48-50.

19 Jafri W, Yakoob J, Abid S, Siddiqui S, Awan S, Nizami SQ. Helicobacter pylori infection in children: population-based agespecific prevalence and risk factors in a developing country. Acta Paediatr 2010; 99: 279-82. 
20 Clayton CL, Mobley HLT eds. Helicobacter pylori protocols (Methods in molecular medicine series) 3rd edn. Totowa: Humana Press, 2002: 33.

21 Fox JG, Dewhirst FE, Shen Z et al. Helicobacter species identified in bile and gall bladder tissue from Chileans with chronic cholecystitis. Gastroenterology 1998; 114: 755-63.

22 Hamada T, Yokota K, Ayada K et al. Detection of Helicobacter hepaticus in human bile samples of patients with biliary disease. Helicobacter 2009; 14: 545-51.

23 Atherton JC, Cao P, Peek RM, Tummuru MK, Blaser MJ, Cover TL. Mosaicism in vacuolating cytotoxin alleles of $H$. pylori: association of specific vacA types with cytotoxin production and peptic ulceration. J Biol Chem 1995; 270: 17771-7.

24 Covacci A, Rappuoli R. PCR amplification of gene sequences from Helicobacter pylori strains. In: Helicobacter pylori: techniques for clinical diagnosis and basic research. Philadelphia: Saunders, 1996: 94-109.

25 Marzio L, Angelucci D, Grossi L, Diodoro MG, Di Campli E, Cellini L. Anti-Helicobacter pylori-specific antibody immunohistochemistry improves the diagnostic accuracy of Helicobacter pylori in biopsy specimen from patients treated with triple therapy. Am J Gastroenterol 1998; 93: 223-6.
26 Goldstein NS. Chronic inactive gastritis and coccoid Helicobacter pylori in patients treated for gastroesophageal reflux disease or with H. pylori eradication therapy. Am J Clin Pathol 2002; 118: 719-26.

27 Chen DF, Hu L, Yi P, Liu WW, Fang DC, Cao H. H. pylori exist in the gall bladder mucosa of patients with chronic cholecystitis. World J Gastroenterol 2007; 13: 1608-11.

28 Caldwell MT, McDermott M, Jazrawi S et al. Helicobacter pylori infection increases following cholecystectomy. Ir J Med Sci 1995; 164: 52-5.

29 Figura N, Cetta F, Angelico M et al. Most Helicobacter pyloriinfected patients have specific antibodies, and some also have H. pylori antigens and genomic material in bile: is it a risk factor for gallstone formation? Dig Dis Sci 1998; 43: 854-62.

30 Tompkins DS, West AP. Campylobacter pylori, acid and bile. J Clin Pathol 1987; 40: 1387.

31 Magnuson TH, Lillemoe KD, Zarkin BA, Pitt HA. Patients with uncomplicated cholelithiasis acidify bile normally. Dig Dis Sci 1992, 37: 1517-22.

32 Dutta U, Garg PK, Kumar R, Tandon RK. Typhoid carriers among patients with gallstones are at increased risk for carcinoma of the gall bladder. Am J Gastroenterol 2000; 95: 784-7. 